\title{
Determinants of Tax Attitude and Tax Compliance among Small and Medium Enterprises (SMEs) in Tourism Industry: A Survey Study in Georgia
}

\author{
Yesim Helhel \\ Tourism Faculty, Department of Tourism Management \\ Akdeniz University, 07058, Konyaaltı, Antalya, Turkey \\ Mamisa Varshalomidze \\ Tourism Faculty, Department of Tourism Management \\ Akdeniz University, 07058, Konyaaltı, Antalya, Turkey
}

\begin{abstract}
The aim of this study is to seek out factors that affect attitudes and considerations of taxpayers on tax compliance in tourism industry in Georgia. The factors were determined according to the previous literature, and classified as internal \& external. The majority of recent researches on tax compliance focused on individuals, not on firms. In this paper, we use data collected from Small and Medium Enterprises (SMEs) in tourism industry in Georgia. A questionnaire was designed by using a five point Likert scale and filled out with face-to-face interview. Cronbach's alpha coefficient widely used to measure internal consistency was obtained as 0,837 in this study. The findings show that internal factors seem to be much more effective determinants on tax compliance than external ones. Their opinions about current situation do not differ from as it should be. Ability to pay tax, accurate tax payment, raising tax morale and consciousness of citizens, and reassessment of deterrence policies (such as exemption, audit, penalty and fine) have been perceived as contributing factors toward compliance behavior among taxpayers. It is also found that there is no statistically significant difference in the perception and attitudes of respondents to taxation according to age and location of firms, but there are a few differences according to their ownership and subsector.
\end{abstract}

Keywords: Georgia, SMEs, Tax compliance, Tourism industry, Subject classification codes.

\section{INTRODUCTION}

Georgia, like other post-communist countries that merged from a centrally- planned economies to market-based economies has established a dynamic business environment including a modern tax system similar to Western style during the last decades. Before the Rose Revolution in 2003, Georgia had a poor tax system that involved widespread tax evasion and avoidance, tax law deficiencies, and corruption of institutional frameworks. Although Georgia had high tax rates, tax revenue collection did not exceed 15 percent of GDP (Gurgenidze, 2009). The government was thus incapable of funding even the most basic public services and maintaining critical infrastructure. Schneider et al. (2010) found that Georgia had the highest shadow economic activity in the period of 1999 to 2007 among 21 transition countries (TCs, Post-communist countries). After the Rose Revolution, the government committed itself to deeply reforming the tax system, hoping to reduce the instances of both tax and administrative 
abuse. After a year of discussion and debate, the number of taxes and their rates were reduced to the lowest levels in the region at the end of 2004 (Torosyan and Filer, 2012). In 2005, Georgia enacted a new tax code introducing lower and flat- tax rates, significant procedural and institutional innovations (Batumi Investment Agency Report, 2011). It was a major change in the Georgian fiscal policy. In this way, low tax rates were adopted and 21 different taxes applied in 2004 were reduced to 6 in 2005. As a result of tax cuts and overhaul of the tax code, system has been improved by 2010. In 2009, Georgia was ranked fourth-best performer worldwide by the Forbes Tax Misery and Reform Index. In 2010, another new tax code was enacted to consolidate the tax and customs rules into a single code. Implemented new code aimed three main objectives: 1 . Taxes should be simplified, 2 . Trust in the tax system should be increased, 3. Georgian tax legislation should be better aligned with international best practice and EU directives (PricewaterhouseCoopers, 2011). In the following years, Georgia developed a broad range of e-government services, often using online tax filing system as a starting point, and the infrastructure for e-government by introducing electronic structure. As a result, Georgia became a nation of neoliberal reforms (Papava, 2014).

Today, Georgia has a tax system consistent with the free market economy, and it had been ranked 9th in the Ease of Doing Business in 2013 (12th in 2012, 11th in 2010) according to The World Bank and International Finance Corporation (IFC). Georgia's position in the Index of Economic Freedom has improved as well. Georgia ranks 21st in the 2013 survey made by the Heritage Foundation, and the Corruption Perception Index for Georgia is 51, which is the best ranking in the region according to Transparency International (Business Climate in Georgia KPMG Report, 2013). Tax legislation has been based on equity and neutrality principles. However, application of tax legislation has been failed, even misused quite often. The state's effort to improve tax administration has had precious few positive results, and most of the people believe that tax collecting structures are corrupted and tax evasion has been usual in the structure. Parallel to them, tax inspectors believe that the majority of people employed in the private sector are officially not registered and great majority of self-employed evade taxes. There have been often conflict situation between administration and taxpayer due to ambiguity of tax laws. In spite of decline in the tax rates, low taxes don't contribute to economic growth. Taxation has not been used as a lever to promote job creation in specific sectors or regions, and to solve public problems, such as struggle with poverty, urban development or investment to new growing sectors, especially in service sectors like tourism.

Tourism is one of those potential sectors that Georgia can increase its income with ease. Thus, it is clear that tourism can play a valuable role in stimulating higher growth, creating employment, reducing regional asymmetries, and bringing about positive externalities that affect other economic activities, directly or indirectly (Margvelashvili et al, 2014). The presence of rich tourism potential in the country contributes to the development of virtually all types of tourism, such as rural, rest and recreation, business, cultural, wine and adventurer (Korganashvili, 2013). However, the potential which exist in the country is underutilized and investment needed into the infrastructure to encourage tourism is probably to pose a problem. Erkomaishvili et al. (2014) found the factors impeding the development of tourism industry in their study, namely - existence of the conflict zones, high rates of the bank credits, deficiencies associated with the tax laws, low level of infrastructural development, low quality of services, deficit in the competitive staff, excessive increase of prices in the peak seasons, insufficient promotion of the touristic opportunities of Georgia on the international market.

Due to the role of tourism in the sustainable development of a country and in the growth of wellbeing of its citizens, it is important to explore and assess attitude and compliance of tourism industry towards taxation. Alm and Martinez-Vazquez (2003) classified determinants 
of tax compliance into two basic categories; The first category relates to how the taxpayer judges his/her own compliance behavior in light of the individual's own feelings about what is proper, acceptable, or moral behavior, might be termed as internal norms. The second relates to perception of taxpayer about fairness of tax system, level of transparency and accountability of government, level of corruption, technological capability of tax office, and complexity in the tax laws, inadequate tax knowledge, approach of tax administration to taxpayers, might be termed as external norms. Hazman (2009) focused on external variables and found that failure in fiscal transparency and deficiency to submit public goods and services have a strong meaningful effect on tax compliance. Especially, trust in government affects tax compliance of citizens, and increases the tendency to declare taxable revenue more precisely (Alm et al, 1992; Alm and Torgler, 2006). Individual perceptions of good governance may increase tax compliance. When the services provided by the government are viewed as widely desired, and the decisions determining services provided are transparent and fair, compliance is expected to be higher. The close effect of tax authority's supervision on timely tax payments shows no positive overall effect on tax compliance. Interestingly, supervision through friendly deterrence leads to delayed tax payments, and causes a crowding out of intrinsic tax compliance (Gangl et al, 2014). However, it has also been found that customer oriented tax administration fosters voluntary tax compliance of citizens (Mutlu and Taşcl, 2013). High tax rates and complex filing procedures are the most crucial external determinants of noncompliance, apart from multiple taxation and lack of proper enlightenment (Atawodi and Ojeka, 2012). Observed tax compliance behavior cannot be explained entirely with the traditional economic analysis that focuses mainly on deterrence components, such as the impact of audit, penalty, and tax rates. It has also been suggested that tax morale, in other words, "the intrinsic motivation to pay taxes", might help explain the puzzle of why so many individuals pay their taxes (Alm and Torgler (2006). Compliance is higher if the citizens are well-informed about outcome of the vote, and taxes are spent in ways consistent with the preferences of the citizens (Alm et al, 1993). The study conducted by Cummings, et al (2004) by using data from field and laboratory experiments from the United States, Botswana, and South Africa revealed that observed differences in tax compliance and tax morale levels can be explained by differences in the fairness of tax administration, perceived fiscal exchange and overall attitude towards the respective governments across the countries. The studies conducted on tax compliance are based on surveys analyzing individual taxpayer considerations and self-reports or empirical researches that mainly cooperate with students. However, the empirical researches on firm tax compliance are limited. These studies had used firm data, and field studies or laboratory experiments to provide further evidence on tax compliance (Kirchler, 1999; Hazman, 2009; Alm and McClellan, 2012; Nkwe, 2013; Razak and Adafula, 2013; Gangl et al, 2014; Nyamwanza et al, 2014).

As a novelty in this study, we conduct a quantitative study for tax compliance assessment focusing on firms in tourism industry. This study intends to (1) investigate the determinants of tax compliance by classifying them as internal and external, and (2) reveal taxpayers' perceptions about tax system in Georgia. Moreover, this paper can contribute to the literature in two ways: (1) The information derived will add to poor literature available for Georgia, and (2) The information about determinants of tax compliance enables Georgian policy makers to enhance the impact of positive variables and mitigate the impact of negative ones so that high voluntary tax compliance can be ensured in the future.

\section{THE METHODOLOGY}

A quantitative study was adopted to gather information from the financial / chief account managers of tourism operators running small or medium-sized enterprises in Batumi, Tbilisi 
and Kutaisi regarding their attitudes and perceptions toward tax compliance. According to the Ministry of Finance, the term "SME" in Georgia refers to any firm generating annual turnover of less than GEL 1,500,000 (roughly $\$ 850,000$ at the time of writing), regardless of the number of employees (Caucasus Research Resource Centers, 2014). The sample consists of 74 firms including hotel, travel agency, food \& beverage and others (car rental service, souvenir shop, tour guidance etc.). The questionnaire was adapted from the previous studies conducted to measure the effects of internal \& external factors on tax awareness \& compliance (Helhel and Ahmed, 2014; İpek and Kaynar, 2009; Aljaadi et al., 2009). All questionnaires were filled out with face-to-face interview. The questionnaire was divided into two sections such that Section 1 was designed to obtain characteristics of firms (subsector, experience, location and ownership), and Section 2 consisting twenty-two (22) statements was designed to evaluate attitudes of tax payers against tax. A five-point Likert scale (from1 strongly disagree to 5 strongly agree) was used to indicate disagreement or agreement of the subject with each statement. Internal consistency of answers given to the questionnaire was also examined by reliability analysis. Cronbach's alpha coefficient that is widely used to measure internal consistency of Likert scale \& two resulted dichotomous variables in social sciences, and a calculated value of alpha between 0.7 and 0.95 that tells that the instrument used to measure variables of the study has fulfilled the validity \& reliability (Tavakol and Dennick, 2011). Aforementioned method was applied on the 22 statements indicating opinions and attitudes of respondents, and this coefficient was obtained as 0,837.

This study is subject to some limitations such that questionnaires were applied only to 74 firms liable to pay. So, the results have not shown a whole picture of sector in Georgia. Several studies are required to generalize the results of this study \& fill in this gap. The second limitation of this research is that thoughts of respondents are limited to the time in 2014. Moreover, sampled respondents may not have answered all questions with candor, so the results of this research based on the opinions of the sampled group might not accurately reflect the opinions of members of the included population. This is more so because, people generally feel reluctant to divulge their real opinions (Razak and Adafula, 2013). Finally, this research is conducted to explore the financial / chief account managers of tourism operators in Georgia towards taxation process using questionnaire. So, the results obtained in this research are limited in terms of methodological approaches using present questionnaire. In order to confirm and enlarge the scope of these results, more surveys (interviews about supervision of tax authorities, perceived restrictions, legal process etc) need to be held on.

\section{ANALYSIS AND RESULTS}

The sample consists of 74 SMEs activating in tourism industry. Of the questionnaires retrieved, $31.1 \%$ are from travel agencies, 28, 4\% are from food \& beverage, 23\% are from hotels, and the remaining $17.6 \%$ of the SMEs are from car rental service, souvenir shop and tour guidance businesses. $48.6 \%$ of them are new businesses ( 1 to 5 years old), $29.7 \%$ of them are 6 to 11 years old, $13.5 \%$ of them are 12 to 20 years old, and only $6 \%$ of them are older than 20 years. This distribution shows that the majority of the firms (approximately $79 \%$ of them) is newly established (11 years and less). The survey of this study was held in Tbilisi (28.4\%) which is the capital city of Georgia, Batumi (51.4\%) and Kutaisi (20.3\%) which are the most important tourism destinations of Georgia. The majority of the firms were domestic (70.3 \%).

Table 2 lists the eight statements including internal factors and overall mean scores for each statement. Respondents were asked to choose a number between 1(one) and 5 (five) to indicate the extent of their disagreement or agreement with each statement. 
Table 1. Characteristics of Firms

\begin{tabular}{|c|c|c|c|}
\hline \multicolumn{2}{|c|}{ Characteristics of Firms } & Number of Firms & Percent \\
\hline \multirow{8}{*}{ 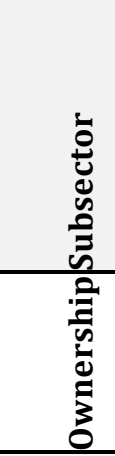 } & Hotel & 17 & 23 \\
\hline & Travel Agency & 23 & 31.1 \\
\hline & Food \& Beverage & 21 & 28.4 \\
\hline & Others & 13 & 17.6 \\
\hline & Sub Total & 74 & 100 \\
\hline & Domestic & 52 & 70.3 \\
\hline & Foreign & 22 & 29.7 \\
\hline & Sub Total & 74 & 100 \\
\hline \multirow{5}{*}{ 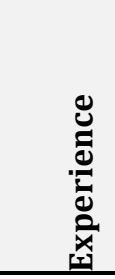 } & $1-5$ years & 36 & 48.6 \\
\hline & $6-11$ years & 22 & 29.7 \\
\hline & $12-20$ years & 10 & 13.5 \\
\hline & 20-above & 6 & 8.2 \\
\hline & Sub Total & 74 & 100 \\
\hline \multirow{4}{*}{ 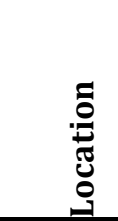 } & Tbilisi & 21 & 28.4 \\
\hline & Batumi & 38 & 51.4 \\
\hline & Kutaisi & 15 & 20.3 \\
\hline & Sub Total & 170 & 100 \\
\hline
\end{tabular}

As it is shown in Table 2, approaches of tax payers about taxation in the light of internal factors have been varied. Three points (3) located in the middle scoring has been considered to be "neither satisfied nor dissatisfied". One-sample t-test was applied whether there is statistically significant difference by taking the average of the scores given to the statements according to point 3 that is "neither satisfied nor dissatisfied". As can be seen in Table 2 \& Table 3, since the p values of all statements are less than 0,05 at 95\% confidence interval of the difference, these differences assessed as statistically significant. It means that overall mean scores can be regarded more disagree below point 3 , and regarded as more agree above point 3 than to be "neither satisfied nor dissatisfied" (Abdieva et al, 2011).

The strongest agreement in terms of the mean scores was that tax payment is a sacred duty. Some empirical studies tended to show that religiosity might influence people's habits, and might make individuals reluctant to engage in tax evasion, and a higher religiosity is correlated with higher tax morale (Alm and Torgler, 2006). The political endorsement of tax subject to the state as well as allegiance is the second strongest agreement that effect on tax compliance. Since mutual relationship between the majority of tax payers and state has been positive in terms of their approaches towards tax, feeling of displeasure due to tax payment will be less felt. Moreover, these citizens attribute greater legitimacy to administration and be more compatible to the laws than citizens with negative perceptions (Tunçer, 2002).Loyalty with the state may be enhanced by permitting citizens to participate actively in the political process and to express their preferences (Alm \& Torgler, 2006). The third strongest statement is the opinion of a tax payer about other tax payers' obligations. The general opinion of tax payers about reluctance of others to meet their tax obligations may affect them in all of the countries. Tax payers that have paid taxes on time and accurately may feel to be deceived against others that haven't regularly paid, then this situation may lead to negative orientation and defiance (Demircan, 2003). The prevalent opinion is that tax payers are not taxed according to their ability in Georgia among the respondents. This situation can be identified with the principles of 
horizontal and vertical equity. The first theory suggests that people with the same ability to pay should pay the same amount ((horizontal ability-to-pay equity), and the second emphasizes a tax subject with a higher ability to pay should pay a higher amount (vertical ability-to-pay equity) (Meşca, 2013). According to these theories, taxpayers have to be forced to give up a certain amount of wealth, directly or indirectly. The following strong agreement is that "so many tax subjects evade tax, so I also have a right to evade tax". Evidence suggests that perceptions about the honesty of others may affect compliance behaviour. The first disagreement statement is that collected taxes are not well-spent as public service in Georgia. In other words, respondents indicated that they are moderately benefiting from governments' use of public funds. Razak and Adafula (2013) indicated that taxpayers may continue to comply with their tax obligations if the perceived benefits from government increased, even though their tax burdens were high. The existence of positive benefits may increase voluntary compliance of citizens, without direct coercion. Similarly, the respondents support the statement that needs of tax payers are taken into account in determining tax policies. When the requirements \& preferences of tax payers have not been paid attention, the attitudes of them have not been clear against tax policies, especially in totalitarian regimes (Çataloluk, 2008). There is also some anecdotal evidence that individuals are less inclined to pay their taxes when they feel that they have little say in government decisions and when government is perceived as unresponsive to their wishes (Alm et al, 1993).

Table 2: Summary of Responses Related with Internal Factors

\begin{tabular}{|l|l|l|l|l|}
\hline & & & $\begin{array}{l}\text { Std. } \\
\text { Deviatio } \\
\text { n }\end{array}$ & $\begin{array}{l}\text { P } \\
\text { value }\end{array}$ \\
\hline $\begin{array}{l}\text { S4- Collected tax is not equivalent to public goods in Georgia } \\
\text { S16-Requirements of tax payers are not taken into account in } \\
\text { determining tax policies }\end{array}$ & 74 & 2,58 & 1,517 &, 005 \\
S17-Tax payers do not pay taxes on ability to pay in Georgia & 74 & 3,92 & 0,962 &, 000 \\
S18-Tax payers are not paying taxes accurately in Georgia & 74 & 3,93 & 0,956 &, 000 \\
S19-The mentality "why I am not evading tax, everyone on tax & 74 & 3,63 & 0,751 &, 000 \\
evasion" is prevalent among tax payers in Georgia & & & &, 000 \\
S20- Reluctance of someone else to meet tax obligations \\
affects me
\end{tabular}

The external factors (resulted in economic \& political situations, structures of tax system \& tax administration) may also be effective on compliance behavior. The majority of the respondents reported that existence of unrecorded transactions that generate tax revenue is not ethical behavior. Furthermore, tax penalties, extensive tax exemptions and tax amnesties granted frequently are considered inefficient methods for strategy of equality by respondents. There is no doubt that audit is adequate to levy tax, but tax fines and penalties are not considered enough for deterrence policy. Experiments on tax behavior in the laboratory have consistently supported the positive impact of audits and fines on compliance. Nonetheless, the effects were rather weak. Field studies and surveys have yielded effects that are lower than, and sometimes the opposite of the predicted effects (Gangl et al, 2014). Cummings et al (2009) stated that reducing tax evasion is often not simply a matter of applying higher penalties and/or increasing the frequency of audits, and extreme penalties may backfire by creating a setting in which bribery and corruption is more prevalent with the end result being lower tax compliance and a general loss of trust in public institutions. They argued that the responses to the usual enforcement mechanisms (audits and penalties) are shown to be enhanced by individual perceptions of good governance that include a fair tax system, a government 
providing valued goods and services in return for tax revenues, and a political system that is not corrupt. Tax rates and tax system are not generally perceived to be high and unfair in Georgia by respondents, respectively. There have been many studies concentrated on tax rate and fairness on compliance. One of these studies realized by Etzioni (1986) documented that the fairness perception is more likely to affect tax compliance rather than tax rates. The author also found that tax evasion has increased as citizens have been considering taxes unfair, even as tax rates remained stable. Surprisingly, the majority of taxpayers do not think about tax law as complex, moreover, supports recurrent reform of tax law. Razak and Adafula (2013), in their research on Gana found that older business operators may better understand the tax laws, and consequently may be better positioned to evaluate their burden of taxes. A significant statistical positive relationship was found between understanding level of tax laws and tax compliance in this study. Similar findings were documented by Nkwe (2013), Saad (2012) and Kirchler et al (2006). Tax system is a complex and significant structure to ensure the success for taxation. In this survey, the majority of respondents have considered about number of tax officers as sufficient, their professional knowledge, training and respectful treatments to taxpayers as adequate. Alm and McClellan (2012) reported that providing better taxpayer services make easier for firms to pay their taxes and reduce obstacles to compliance. Respectful treatment includes that tax officers see it as their task to advise taxpayers and to perceive taxpayers as cooperative individuals, and not as savvy citizens searching for loopholes to escape the law (Hofmann et al, 2012).

Table 3: Summary of Responses Related with External Factors

\begin{tabular}{|c|c|c|c|c|}
\hline & $\mathrm{N}$ & Mean & $\begin{array}{l}\text { Std. } \\
\text { Deviatio } \\
\mathrm{n}\end{array}$ & $\begin{array}{l}P \\
\text { value }\end{array}$ \\
\hline S1- Tax rates are too high in Georgia & 74 & 2,57 & 1,518 & 005 \\
\hline S2- Tax system is unfair in Georgia & 74 & 2,39 & 1,467 & 000 \\
\hline S3- Tax law is not simple and clear in Georgia & 74 & 2,34 & 1,446 & 000 \\
\hline S5- Recurrent tax reforms lead to inadequate application & 74 & 2,39 & 1,460 & 000 \\
\hline S6- Tax system is not adaptive to economic situation & 74 & 2,44 & 1,527 & 000 \\
\hline S7- Tax audit is not deterrent sufficiently in Georgia & 74 & 2,56 & 1,664 & 000 \\
\hline S8- Tax penalties are not deterrent sufficiently in Georgia & 74 & 3,58 & 1,194 & 000 \\
\hline $\begin{array}{l}\text { S9- Existence of unrecorded transactions that generate tax } \\
\text { revenue is not ethical behavior }\end{array}$ & 74 & 4,27 & 1,275 & 000 \\
\hline S10-Tax amnesties granted frequently result in tax inequality & 74 & 3,20 & 1,638 & ,002 \\
\hline S11- Extensive tax exemptions result in inequality & 74 & 3,27 & 1,621 & 000 \\
\hline $\begin{array}{l}\text { S12- Number of staff working in the tax office is not sufficient } \\
\text { for effective service }\end{array}$ & 74 & 2.18 & 1,576 & 000 \\
\hline $\begin{array}{l}\text { S13- Orientation \& professional knowledge of staff working in } \\
\text { the tax office is not adequate for effective service }\end{array}$ & 74 & 2.29 & 1,529 & 000 \\
\hline $\begin{array}{l}\text { S14- Relationship between staff working in the tax office and } \\
\text { tax payers are not positive }\end{array}$ & 74 & 2,32 & 1,582 & 000 \\
\hline $\begin{array}{l}\text { S15- Tax office is unable to adapt to technological } \\
\text { developments }\end{array}$ & 74 & 2,10 & 1,584 & ,000 \\
\hline
\end{tabular}

The perception and attitudes of the tax subjects to taxation are analyzed whether there is significantly difference according to ownership and subsectors or not in this stage. It was found that distribution of data was not normal according to Kolmogrov-Smirnov normality test ( $\mathrm{p}<0$, $05)$, and data did not have homogenous distribution in terms of total values $(\mathrm{p}<0,05)$. Therefore, comparative analysis based on subsector and ownership was done with nonparametric analysis in all 22 statements without any distinction as internal and external. Table 4 shows that there are significant differences between domestic \& foreign firms in terms of only three statements including one internal and two external factors. It can be said that 
domestic firms have tendencies to behave more compliant than foreign firms, except for statement 11 that is about extensive application of tax exemption. It can be generally said that the role of ownership impact has been only for 3 factors on compliance in Georgia.

Table 4: Mann Whitney U Test Related with Internal \& External Factors-Ownership

\begin{tabular}{|c|c|c|c|c|c|}
\hline Statements & Ownership & $\begin{array}{l}\text { Mean } \\
\text { Rank } \\
\end{array}$ & M-W U & $\mathbf{Z}$ & P-Value \\
\hline \multirow{2}{*}{$\begin{array}{l}\text { S6-Tax system is not adaptive to economic } \\
\text { situation* }\end{array}$} & Domestic & 40,87 & \multirow{2}{*}{397} & \multirow{2}{*}{-} & \multirow{2}{*}{0,031} \\
\hline & Foreign & 29,55 & & & \\
\hline \multirow{2}{*}{$\begin{array}{l}\text { S11-Extensive tax exemptions result in } \\
\text { inequality* }\end{array}$} & Domestic & 34,35 & \multirow{2}{*}{408} & \multirow{2}{*}{-} & \multirow{2}{*}{0,042} \\
\hline & Foreign & 44,95 & & & \\
\hline \multirow{2}{*}{$\begin{array}{l}\text { S16-Requirements of tax payers are not taken } \\
\text { into account in determining tax policies }\end{array}$} & Domestic & 40,62 & \multirow{2}{*}{410} & \multirow{2}{*}{$\begin{array}{l}- \\
1,995\end{array}$} & \multirow{2}{*}{0,046} \\
\hline & Foreign & 30,16 & & & \\
\hline
\end{tabular}

Kruskall-Wallis test is a nonparametric alternative of one-way ANOVA (the one-way analysis of variance between groups), and provides to compare three or more groups with continuous variables. Each person must be in different group, since it is an inter-group analysis (Kalaycl, 2006). The values are converted to sequential row and their averages are compared with each group. Aforementioned test was used to investigate the respondents' approaches to taxation whether there is statistically significant difference according to the subsectors or not. Applied test results for internal and external factors are represented in Table 5. There are significant differences for only four statements, 2 of them are external. Mann-Whitney $U$ test was performed for these statements in order to determine which subsector is statistically different from each other. Throughout Table 5; $\mathrm{H}$ indicates hotel, TA indicates travel agency, and F\&B indicates food and beverage.

Table 5: Kruskall Wallis Test Related with Internal \& External Factors-Subsector

\begin{tabular}{|c|c|c|c|c|c|c|c|}
\hline \multirow[t]{2}{*}{ Statements } & \multicolumn{4}{|c|}{ Mean Rank / Subsector } & \multirow{2}{*}{$\chi^{2}$} & \multirow{2}{*}{$\mathbf{P}$} & \multirow{2}{*}{$\begin{array}{l}\text { Significant } \\
\text { Difference }\end{array}$} \\
\hline & Hotel & $\begin{array}{l}\text { Travel } \\
\text { Agency }\end{array}$ & $\begin{array}{c}\text { Food \& } \\
\text { Beverage }\end{array}$ & Other & & & \\
\hline $\begin{array}{lrr}\text { S8-Tax penalties are } & \text { not } \\
\text { deterrent } & \text { sufficiently } & \text { in } \\
\text { Georgia* } & & \\
\end{array}$ & 23,62 & 47,22 & 41,38 & 32,19 & 14,777 & 0,002 & $\begin{array}{l}\mathrm{H}-\mathrm{TA} \\
\mathrm{H}-\mathrm{F} \& \mathrm{~B} \\
\text { TA -Others }\end{array}$ \\
\hline $\begin{array}{l}\text { S9-Existence of unrecorded } \\
\text { transactions that generate tax } \\
\text { revenue is not ethical } \\
\text { behavior* }\end{array}$ & 32,68 & 40,46 & 30,12 & 50,50 & 11,841 & 0,008 & $\begin{array}{l}\mathrm{H} \text { - Others } \\
\mathrm{TA} \text { - Others } \\
\text { F\&B - Others }\end{array}$ \\
\hline $\begin{array}{l}\text { S21-Tax payment is a sacred } \\
\text { duty for me }\end{array}$ & 32,29 & 41,02 & 32,93 & 45,50 & 8,450 & 0,038 & $\begin{array}{l}\text { H - Others } \\
\text { F\&B - Others }\end{array}$ \\
\hline $\begin{array}{l}\text { S22- Tax payment is an } \\
\text { indicator of loyalty to state }\end{array}$ & 32,15 & 40,67 & 33,40 & 45,50 & 7,970 & 0,047 & $\begin{array}{l}\text { H - Others } \\
\text { F\&B - Others }\end{array}$ \\
\hline
\end{tabular}

\section{CONCLUSION}

This study was conducted to survey voluntary tax compliance tendency of SMEs activated in tourism industry located in the most promising tourism destinations in Georgia in terms of internal and external factors. Georgia, as developing and post-communist country has made progress to develop policies and institutions, specifically targeting SMEs by increasing publicprivate dialogue and inter-governmental coordination. SMEs play an important role as key engines for economic growth and development in all developing and transitional countries, including Georgia. In recent years, tourism has been main priority sector for Georgia to ensure sustainable development of the country. Therefore, Georgia improved the business 
environment by offering various incentives to investors, including reduction of tax burden and elimination of deficiencies associated with tax laws.

Based on the findings above, it can be generally concluded that SMEs of tourism subsectors have been influenced positive from internal and external factors specifically targeting voluntary compliance. Opinions of taxpayers about current situation do not differ from as it should be. Taxpayers generally advocate fulfilment of tax obligation, at the same time they also denote that current situation contributes to tax compliance positively.

According to the results, internal factors seem to be key determinants to enhance tax compliance in comparison with external factors in Georgia. If the following problems are solved immediately, voluntary tax compliance among SMEs in tourism industry can be promoted:

- Ability to pay tax

- Accurate tax payment

- Raising tax morale and consciousness of citizens

- Reassessment of deterrence policies (penalties, audits and exemptions etc.)

The findings point out that there is no significant difference in the perception and attitudes of respondents to taxation according to age and location of firms, but there are a few differences according to their ownership and subsector.

Since this research points to a broader understanding of tax compliance, more empirical and specific work is needed to better understand tax compliance in Georgia. Moreover, the robustness of these results must be checked in other sectors, other developing and transient countries. Otherwise, these findings cannot be generalized.

\section{ACKNOWLEDGEMENTS}

This study was supported by Akdeniz University, Administration Office of Scientific Research Projects (Akdeniz University, BAP).

\section{References}

1. Abdieva, R., Pirimbaev, J. and Özdil, T., 2011. Kırgızistan'da Vergi Kültürü ve Belirleyenleri, SESSION 5C: Orta Asya Ekonomileri II, pp.335-341.

2. Aljamaree, Y. and Algaylee, A., 2007. Financial Ministry Implements Transparency Principle to Reform the Financial Regulations and Laws (Online), http:// www.sabanews.net/ar/news131480.htm

3. Alm, J., Mccelland, G.H. and Schulze, W.D., 1992. Why Do People Pay Taxes, Journalof Public Economics, Vol 48, Issue: 1, pp.21-38.

4. Alm, J., Jackson, B., McKee, M., 1993. Fiscal Exchange, Collective Decision Institutions, and Tax Compliance, Journal of Economic Behaviour and Organization 22, 285-303, North-Holland

5. Alm, J., Martinez-Vazquez, J., 2003. Institutions, Paradigms, and Tax Evasion in Developing and Transition Countries, Studies in Fiscal Federalism and State-Local Finance, Georgia State University

6. Alm, J., Torgler, B., 2006. Culture differences and tax morale in the United States and in Europe, Journal of Economic Psychology 27 (2006), 224-246

7. Alm, J. and McClellan, C., 2012. Rethinking the Research Paradigms for Analyzing Tax Compliance Behaviour, Tulane Economics Working Paper Series

8. Atawodi, O.W. and Ojeka, S.A., 2012. Factors That Affect Tax Compliance among Small and Medium Enterprises (SMEs) in North Central Nigeria, International Journal of Business and Management, Vol.7, No.12, 88-96. 
9. Caucasus Research Resource Centers, 2014. SME Performances in Georgia and Armenia: Part 1, November 27, 2014.

10. Cummings, R. G., Martinez-Vazquez, J., McKee, M., \& Torgler, B., 2004. Effects of culture on tax compliance: A cross check of experimental and survey evidence, CREMA Working Paper Series, 2004-13, Basel.

11. Cummings, R., Vazguez, M., Torgler, B., 2009. Tax Morale Affects Tax Compliance: Evidence from Surveys and an Artefactual Field Experiment, Journal of Behaviour and Organization, 2304, s.1-11.

12. Çataloluk, C., 2008. Vergi Karşısında Mükelleflerin Tutum ve Davranışları, Selçuk Üniversitesi Sosyal Bilimler Enstitüsü Dergisi, S: 20, Konya, pp. 213-228

13. Demircan, E., 2003. Vergilendirmenin Ekonomik Büyüme ve Kalkınmaya Etkisi, Erciyes Üniversitesi İİBF Dergisi, S.21, Temmuz-Aralık, pp.97-116

14. Erkomaishvili, G., Gvelesiani, R. and Chavleishvili, M., 2014. Policy of Tourism and Opportunities of Development of Wellness Industry in Georgia, International Journal of Social, Education, Economics and Management Engineering, Vol: 8, No: 1

15. Etzioni, A., 1986, Tax Evasion and Perceptions of Tax Fairness: A Research Note, the Journal of Applied Behavioral Science Vol. 22, No.2, 177-185

16. Gangl, K., Torgler, B., Kircler, E. and Hofmann, E., 2014. Effects of Supervision on Tax Compliance: Evidence from a Field Experiment in Austria, Economics Letters, Volume 123, Issue: 3, page: 378-382

17. Gurgenidze, L., 2009. Georgia's Search for Economic Liberty, A Blueprint for Reform in Developing Economies, Amercan Enterprise Institute

18. Hazman, G.G., 2009. Vergi Bilincini Etkileyen Muhtemel Dişsal Etkenlerin Logistik Regresyon Analizi ile Tespiti", Sakarya Üniversitesi SBE, Akademik İncelemeler, Cilt: 4, Sayı: 1, sayfa 53-71.

19. Helhel, Y., Ahmed, Y., 2014, Factors Affecting Tax Attitudes and Tax Compliance: A Survey Study in Yemen, European Journal of Business and Management, Vol.6, No.22, 48-58.

20. Hofmann, E., Hoelzl, E. and Kirchler, E., 2012. Preconditions of Voluntary Tax Compliance: Knowledge and Evaluation of Taxation, Norms, Fairness, and Motivation to Cooperate, Europe PMC Funders Group.

21. İpek, S. and Kaynar, İ., 2009. Vergiye Gönüllü Uyum Konusunda Çanakkale İline Yönelik Ampirik Bir Çalışma, Celal Bayar Üniversitesi İİBF, Yönetim ve Ekonomi, Cilt: 16, S.1, s.173-190.

22. Kirchler, E., 1999. Reactance to Taxation: “Employers' Attitudes toward Taxes”, Journal of SocioEconomics, Volume: 28, page: 131-138.

23. Kirchler, E., Niemirowski, A., \& Wearing, A., 2006. Shared subjective views, intent to cooperate and tax compliance: Similarities between Australian taxpayers and tax officers, Journal of Economic Psychology, Volume 27(4), page: $502-517$.

24. Korganashvili, L., D.(2013), The role of rural tourism in the development of peripheral regions of Georgia, Political factors of economic growth and regional development in transition economies, 6th International Conference on Globalization, Ostrava, Czechia.

25. Margvelashvili, M., Cheishvili, K., Vatsadze, I., 2014. Institutional Foundations of Capitalism and Tourism Management Problems of Countries at the Transition Stage (Case of Georgia)", World Academy of Science, Engineering and Technology International Journal of Social, Education, Economics and Management Engineering Vol: 8, No: 11

26. Meşca, S., L., 2013. The Dynamics of Tax Compliance, Lumen International Conference Logos Universality Mentality Education Novelty, Procedia - Social and Behavioural Sciences, Volume: 92, page: 535-539

27. Mutlu, A. and Taşcı, K., 2013. Vergi Dairelerinin Mükellefe Davranış Biçimlerinin Vergilemede Gönüllü Uyuma Etkisi: Malatya Örneği, Electronic Journal of Social Sciences, Spring-2013, V.12, Issue: 45, pp. 214232.

28. Nkwe, N., 2013. Tax Payers' Attitude and Compliance Behaviour among Small Medium Enterprises (SMEs) in Botswana", Business and Management Horizons, ISSN 2326-0297, Vol. 1, No. 1, page: 113-137.

29. Nyamwanza, T., Mavhiki, S., Mapetere, D. and Nyamwanza, L., 2014. An Analysis of SMEs' Attitudes and Practices toward Tax Compliance in Zimbabwe, SAGE Open, 1-6 
30. Papava, V., 2014. Georgia's Economy, The Search for a Development Model, Problems of Economic Transition", vol. 57, no. 3, pp. 83-94

31. Razak, A., A. and Adafula, C., J., 2013. Evaluating taxpayers' attitude and its influence on tax compliance decisions in Tamale, Ghana, Journal of Accounting and Taxation, Vol. 5(3), 48-

32. Saad, N., 2012. Tax Non-Compliance Behaviour: Taxpayers' View, International Congress on Interdisciplinary Business and Social Sciences, Volume: 65, page: 344-351.

33. Saad, N., 2014. Tax Knowledge, Tax Complexity and Tax Compliance: Taxpayers' View, 2 World Conference on Business, Economics and Management, Procedia- Social and Behavioral Sciences, Volume 109, page: $1069-1075$.

34. Schneider, F., Buehn, A. and Montenegro, C., 2010. Shadow Economies all over the World: New Estimates for 162 Countries from 1999 to 2007, The World Bank Policy Research Working Paper Series, working paper, 5356.

35. Tavakol, M. and Dennick R., 2011. Making sense of Cronbach's alpha, International Journal of Medical Education, 2, ISSN: 2042-6372, pp. 53-55

36. Torosyan, K., and Filer, R., 2012. Tax Reform in Georgia and the Size of the Shadow Economy, IZA DP No.6912, Discussion Paper Series

37. Tunçer, M., 2002, Hükümet-Birey İlişkilerinin Vergi Uyumuna Etkisi ve Türkiye, A.Ü. Siyasal Bilgiler Fakültesi Dergisi, Volume: 57(3), page. 107-128 